\title{
Fiber Orientation Effect on Fracture Toughness of Silk Fiber-Reinforced Zeolite/HDPE Composites
}

Universitas Muhammadiyah Semarang Mechanical Engineering Department Faculty of Engineering Indonesia

Putu H. Setyarini

Associate Professor Brawijaya University Mechanical Engineering Department Faculty of Engineering Indonesia

Agus D. Anggono

Associate Professor Universitas Muhammadiyah Surakarta Mechanical Engineering Department Faculty of Engineering Indonesia
The aim of this work is to investigate the fracture toughness and deformation of silk fiber (SF)-reinforced zeolite (Z)/high density polyathylene (HDPE) composites. The chopped SFs are arranged in the thickness middle of the dry mixture of Z/HDPE powder that has been prepared in a mold. Composites were produced by the compression molding to produce double-edge notch tensile (DENT). The fracture toughness characterization was carried out based on essential work of fracture method. The results show that the presence of SF increased the essential fracture work even though the non-essential fracture work for Z/HDPE was higher than $S-Z / H D P E$. The evolution of plastic zone growth coincides with the growth of the fracture process zone (FPZ) whose height has no effect on energy consumption.

Keywords: fracture, deformation, silk fiber, composite

\section{INTRODUCTION}

In recent years, researchers have turned their attention to the development of natural fibers as a composite reinforcement. The mechanical properties of natural fiber reinforced polymer composites are affected by the distribution and orientation of the added fiber. In the last decade, many studies have reported success in producing thermoplastic matrix composites that are natural fiber reinforced with the orientation of the fibers which are varied in the composites. In previous studies $[1,2]$, mechanical properties of $\mathrm{PP} /$ cellulose fiber composites with randomly oriented fibers have been reported. In an extrusion process in the production of PP/CLY composites, it was reported that the distribution of cellulose fibers in the PP matrix could not be controlled, likewise in an injection molding process [3-7]. As a result, the mechanical properties including fracture toughness are decreased. However, sample specimens consisting of chopped fibers provide better distribution especially when compression molding techniques are applied so the mechanical strength is increased [8-11].

Silk fiber (SF) is a renewable protein biopolymer that is biocompatible and superior in mechanical properties. Therefore, its use is not only in the textile industry but also developed as a biomedical material. Even it has been widely used in medicine for centuries as a suture material [12]. Its excellent biomaterial properties have enamored the concern of researchers to study its prospective use. Studies in orthopedics are focused on developing biomaterials for bone tissue engineering. Silk particles have been used as reinforcement in silk matrix on scaffolds for bone tissue engineering applications [13-15]. At present, silk fibers have been applied as biomaterials for the reconstruction

Received: June 2020, Accepted: September 2020 Correspondence to: Purnomo, PhD, Department of Mechanical Engineering, Faculty of Engineering, Jalan Kedungmundu Raya No. 18 Semarang - Jawa Tengah, Indonesia, E-mail: purnomo@unimus.ac.id doi: $\mathbf{1 0 . 5 9 3 7 / f m e 2 1 0 1 1 2 8 P}$

(C) Faculty of Mechanical Engineering, Belgrade. All rights reserved of bone defects [13, 14, 16, 17] and have shown good properties in biocompatibility, biodegradability, and osteoconductivity $[13,14,18]$. Due to its strength, toughness, and bioresorbable, silk fibers have been used in clinical applications such as postoperative sutures and bone repair $[19,20]$. It has been reported that short SFs have been used as reinforcement in silk fibroin-hydroxyapatite composites manufactured by isostatic compaction methods [21]. Mechanical tests on composites show increased flexural strength and fracture energy caused by the addition of short SFs. By considering its mechanical properties, SFs are very suitable to be added to thermoplastic composites which have been strengthened by bioactive particles as previously investigated [2224]. The incorporation of SF is a good alternative in order to improve fracture toughness and the nature of composite ductile fractures.

In previous works $[25,26]$ it has been reported that the skull implant material from zeolite-HDPE composites has good fracture toughness but its fracture behavior tends to be brittle. This fracture behavior must be given serious attention so that the problem of brittle fracture can be avoided. This work is intended as a response to previous works conducted by Purnomo and co-workers $[25,26]$ related to the improvement of the fracture toughness behavior of Z/HDPE composites used to the skull bone implants application. In this work, chopped silk fiber (SF) was added to the zeolite/HDPE composite as a reinforcement. The SF-reinforced Z/HDPE composite was manufactured by a compression molding technique. The fracture toughness is evaluated while the deformation behavior and the effect of the fracture process zone (FPZ) height on fracture toughness during the fracture process are discussed.

\section{METHODS}

\subsection{Materials and manufactured}

The constituent materials in this study are silk fibers from local Indonesian silkworms, natural mordenite 
zeolite powder taken from East Java, Indonesia, and HDPE supplied by PT Lotte Chemical Titan Nusantara. Both zeolite and HDPE are converted into powder. The dry mixture of zeolite-HDPE powder is set at a composition of 5 wt.\% and 95 wt.\% for zeolite and HDPE, respectively. Silk fiber was chopped about $1 \mathrm{~mm}$ long and added to the zeolite-HDPE powder mixture. The fraction of SF was 3\% by weight of zeolite-HDPE. Chopped SF arranged in the middle thickness of ZHDPE powder with varying SF orientation angles of 0 , 22.5, 45, 67.5, and $90^{\circ}$ (Fig. 1). The distance between $\mathrm{SF}$ chopped is arranged about $2 \mathrm{~mm}$ and carried out in the mold before compression molding was carried out. The press is then closed, the upper and lower mold part being preheated to $120-122^{\circ} \mathrm{C}$, the pressure upraised to about $3,447 \mathrm{kPa}$, and this pressure kept for about 3.5 minutes, for the time of curing to hard, indissoluble and infusible state is achieved. Samples were annealed under atmospheric pressure at $80^{\circ} \mathrm{C}$ for 24 hours.

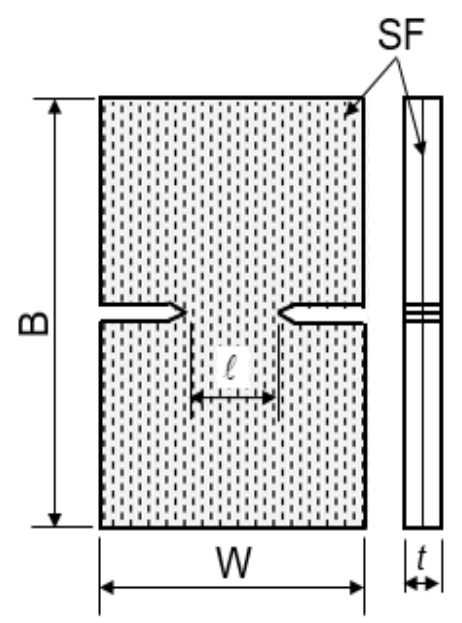

(a)

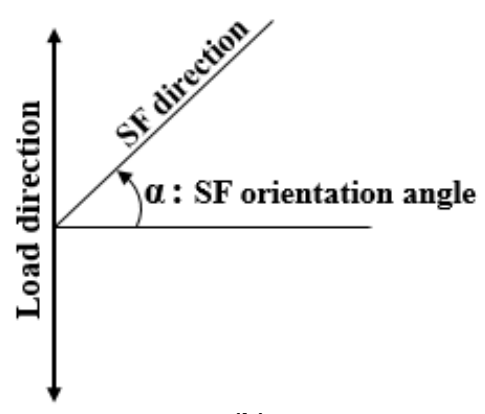

(b)

Figure 1. Illustration schematics of (a) Front and side view of DENT with SF orientation angle of \pm 90 , and (b) load direction and SF orientation angle

\subsection{Mechanical testing}

The fracture test is performed in a quasi-static condition according to the several round-robin tests on an evolving protocol [27-29]. The DENT specimens were subjected to tensile loads using a universal testing machine (UTM) with a cross-head speed of $3 \mathrm{~mm} / \mathrm{min}$ at room temperature. The test data is acquired by a machine controlled by a computer system. During fracture testing, the fracture processes of the DENT specimen in the ligament area were recorded with a video recorder. An experimental setup for fracture test was shown in Fig. 1. Fracture toughness is analyzed using the essential fracture work (EWF) method which separates the total fracture work $\left(W_{f}\right)$ into two different parts namely (i) the work associated with creating new fracture surface, called the essential work of fracture $\left(W_{e}\right)$, and (ii) the work consumed in the plastic deformation zone, called non-essential work of fracture $\left(W_{p}\right)$. Therefore, the $W f$ can be expressed as $[30,31]$ :

$$
W_{\mathrm{f}}=W_{\mathrm{e}}+W_{\mathrm{p}}
$$

The $W_{e}$ and $W_{p}$ are surface and volume related, respectively, and divide them by multiplication between thickness $(t)$ and ligament length $(\ell)$ forming specific work as:

$$
w_{f}=w_{\mathrm{e}}+\beta \cdot w_{\mathrm{p}} \cdot l
$$

where $w_{e}$ is the specific essential and $\beta w_{p}$ is the specific non-essential work of fracture, respectively. Parameter $\beta$ is the plastic zone shape factor. The area under loaddisplacement curve represents the specific total work, $w_{f}$, while $w_{e}$ and $\beta w_{p}$ are the intercept value of linier relationship at zero ligament length and the slope of the regression line on the $w_{f}$ vs $\ell$ curve, respectively.

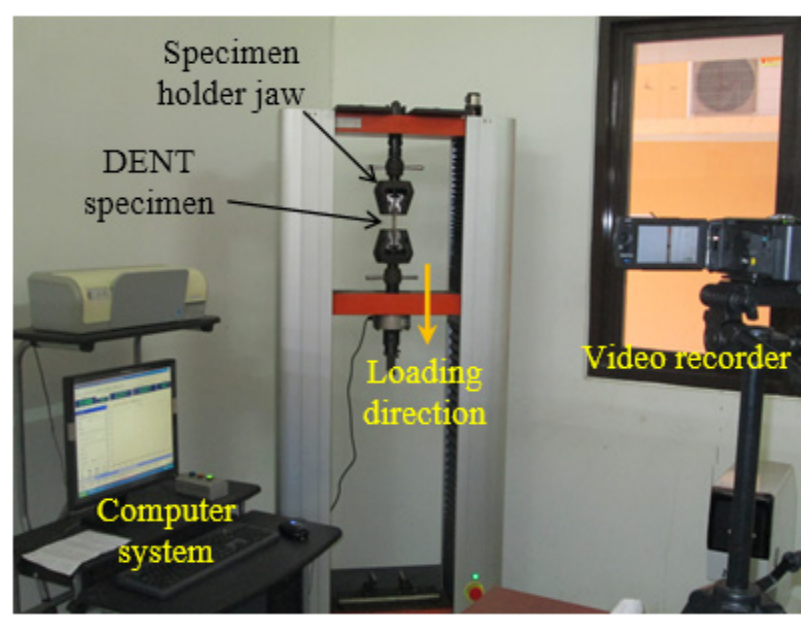

Figure 2. Experimental setup for fracture tests of DENT

\subsection{Fracture surface morphology}

The fracture surface analysis was used through scanning electrone microscope (SEM). Samples were cut from complete fractured DENT and sputter-coated with AuPd prior to examination.

\section{RESULTS AND DISCUSSION}

\subsection{Crack toughness behavior}

The load-displacement curve and the total fracture energy $\left(w_{f}\right)$ as a function of the ligament length $(\ell)$ of the DENT at various orientation angles of SF is presented in Fig. 3. All of the tested DENT curves are of the similar shape and the peak of the curve decreases with increasing orientation angle of SF (Fig. 3a). From observations during the test, the crack was initiated when the load reached the top of the curve (point A) and full yielding at the area of the ligament length is reached at point $\mathrm{B}$. After passing through point $\mathrm{B}$, the crack 
propagates from two notches so that the two crack-tip meets at the mid-length of the ligament which is characterized by a load drop sharply.

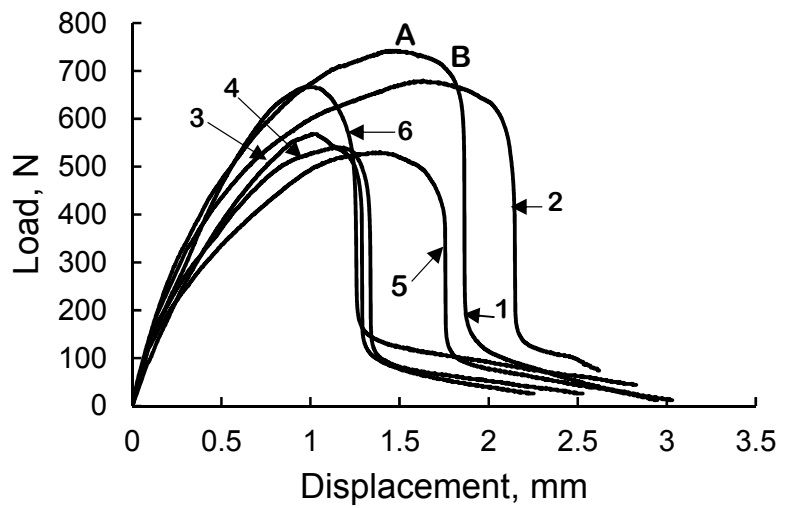

(a)

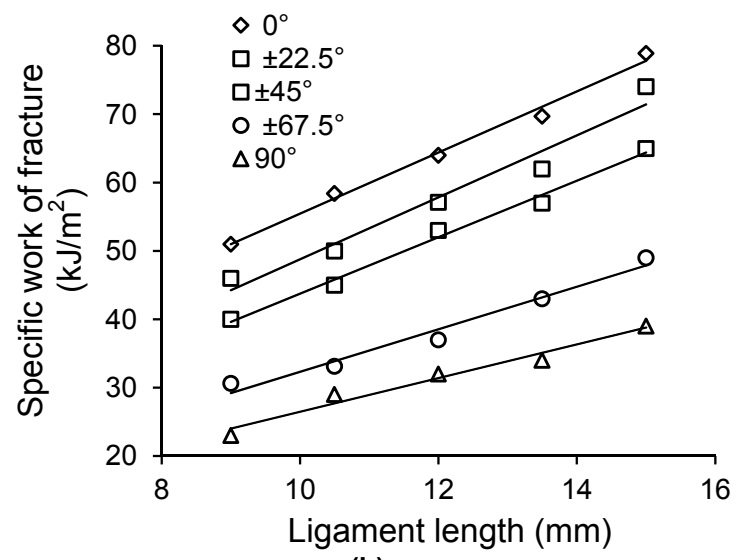

(b)

Figure 3. (a) Typical load-displacement curve of DENT specimens for (1) $0^{\circ} \mathrm{SF}-\mathrm{Z} / \mathrm{HDPE},(2) 22.5^{\circ} \mathrm{SF}-\mathrm{Z} / \mathrm{HDPE}$, (3) $45^{\circ} \mathrm{SF}-\mathrm{Z} / \mathrm{HDPE}$, (4) $67.5^{\circ} \mathrm{SF}-\mathrm{Z} / \mathrm{HDPE}$, (5) $90^{\circ} \mathrm{SF}-\mathrm{Z} / \mathrm{HDPE}$, and (6) Z/HDPE, and (b) Specific total work of fracture versus ligament length in various SF orientation angles.

The materials fracture toughness is analyzed by the EWF approach, therefore the fracture total energy is split into two parts, namely, first, the energy used to create a new fractured surface hereinafter called the essential work of fracture $\left(w_{e}\right)$, second, the energy used for plastic work in the outer plastics zone called as nonessential work of the fracture $\left(\beta w_{p}\right)$. In the form of specific energy, the total energy of the fracture $\left(w_{f}\right)$ as a function of the ligament length $(\ell)$ of the DENT specimen at various orientation angles of SF is shown in Fig. 3b. Based on Fig. 3b, the intercept of the straight line with the $w_{f}$ at zero ligament length is $w_{e}$ and the slope is $\beta w_{p}$.

The average EWF and non-EWF at various SF orientation angles is shown in Fig. 4. It is shown that the EWF of the material drops sharply when the SF orientation angle is enlarged to $22.5^{\circ}$. Upon $0^{\circ}$ the EWF continues to decline even though it is not as sharp as the decrease in value from 0 to $22.5^{\circ}$. The EWF parameter is equivalent to $J_{I C}$ in the $J$-integral method, which shows material resistance to crack initiation [32-34]. Therefore, Fig. 4a indicates that increasing the SF orientation angle decreases the resistance of the material to crack initiation. In the Z-HDPE composite test, the $\mathrm{EWF}=7.45 \mathrm{~kJ} / \mathrm{m}^{2}$ was obtained. This value is indeed below the EWF value in the SF orientation angle of $0^{\circ}$ but is greater than the EWF value in the other material being tested. This is a strong indication that the effect of delamination between fiber and Z-HDPE composites dominates the occurrence of essential fracture decreases by the orientation of the fiber arranged above the angle of $0^{\circ}$.

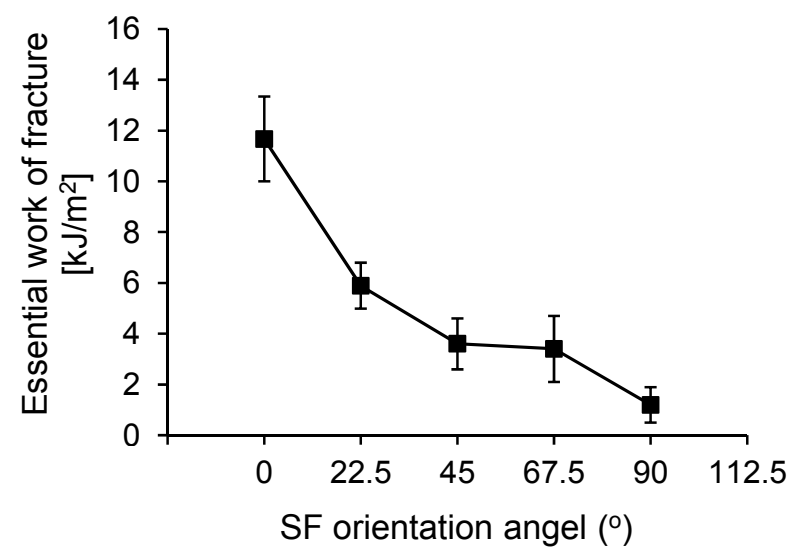

(a)

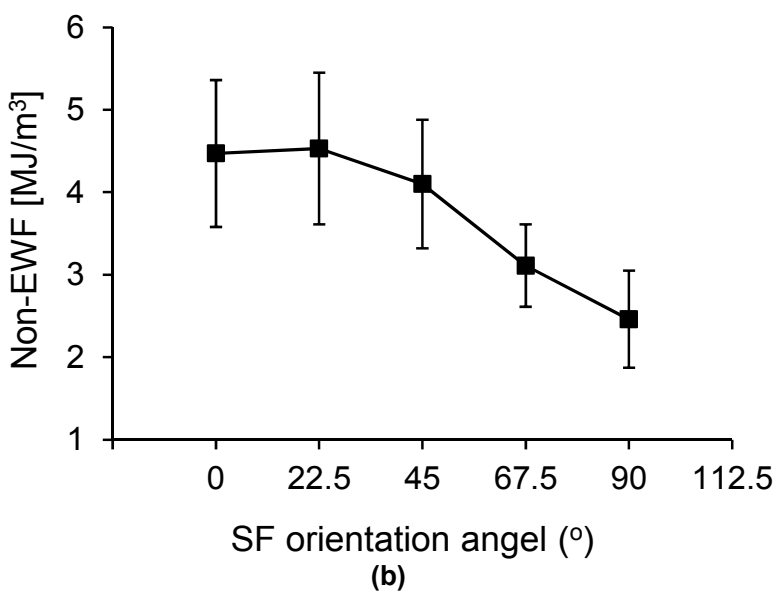

Figure 4. Fracture energy versus SF orientation angles for (a) essential, and (b) non-essential work of fracture

Non-EWF decreases significantly in the SF orientation angle which is set at $45^{\circ}$ and decreases with increasing fiber orientation angle (Fig. $4 \mathrm{~b}$ ). The non-EWF $\left(\beta w_{p}\right)$ on Z-HDPE composites (without SF) is equal to $3.67 \mathrm{MJ} / \mathrm{m}^{3}$ which means lower than non-EWF material at fiber orientation of $0,22.5$, and $45^{\circ}$. The $\beta w_{p}$ parameter is equal to $1 / 4 . d J / d a$ which is the slope of the $J-R$ curve in the application of the $J$-integral method where $a$ is the initial crack length $[32,33,35-37]$. The $d J / d a$ is a parameter that represents toughness against crack propagation. So Fig. $4 \mathrm{~b}$ also reveals that the materials with fiber orientation angle of $0^{\circ}, 22.5^{\circ}$, and $45^{\circ}$ have good resistance to fracture propagation. This is a strong indication that the SF reinforcement effect plays a dominant role in restricting the crack propagation speed.

The crack opening displacement (COD), which is also a measure of the toughness of material fractures, with a material property being a critical COD, has been computed with reference to the practical correlation proposed by Hashemi and co-workers [38, 39]:

$$
w_{e}=C_{f} \sigma_{y} C O D
$$

where $C_{f}$ is equal to 1.15 (for DENT shape specimens) represented a plastic constraint factor, and $\sigma_{y}$ is yield 
stress from the dumbbell test. The COD at various fiber orientation angles are shown in Fig. 5 and indicates a resemblance in the trend to that of $w_{e}$. It has shown a decreasing trend due to the fiber orientation angle which was shifted from $0^{\circ}$ to further up. Conceptually, COD as the opening at the crack tip shows a resistance level to stable crack growth due to the crack blunting effect and the material deformation capacity in the outer fracture process (pastic zone) during fracture process. However, the COD curve trend is similar to $w_{e}$ and there is no similarity to the $\beta w_{p}$ trend (Fig. 4). Therefore, in this case, the COD indicates the parameter of resistance to fracture initiation.

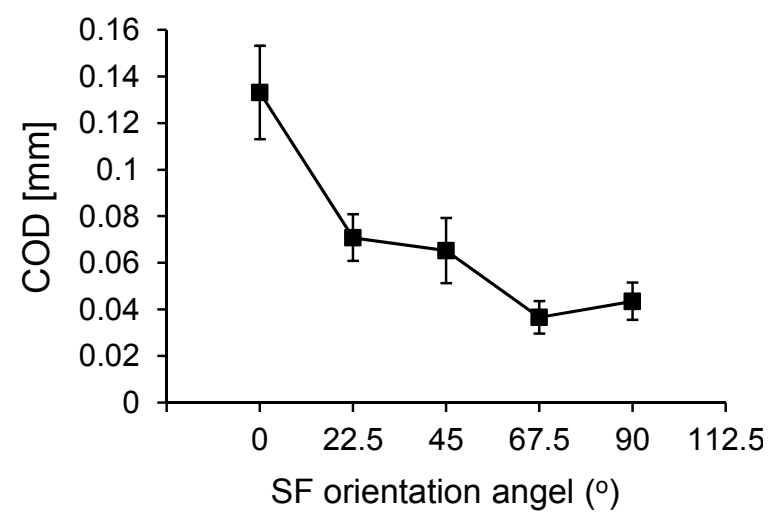

Figure 5. Crack opening displacement versus SF orientation angles

The deformation and fracture development in the DENT test are presented in Fig 6. The top first image show the evolution of the plastic zone, the fracture process zone (FPZ) and the crack initiation when the maximum load is reached, i.e., point A in Fig. 6a. Note that the images depict that the plastic zone in the DENT was not observeable.

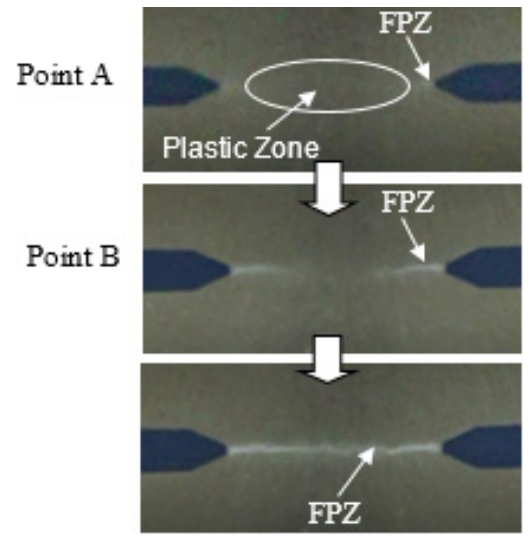

(a)

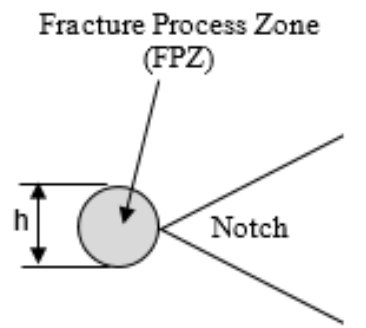

(b)

Figure 6. (a) The development of fracture process zone (FPZ) from point A to the point B of Fig. 5, (b) schematic illustration of FPZ at notch tip
The deformation mechanism associated with crack development can be different at the crack initiation and propagation stage. Before the load has sharply drop (prior to point B in Fig. 6a), the deformation mechanism involves the neck beginning in the entire ligament region and the neck growth in the length of $\ell / 2$ from the notch ends. Subsequent to point B, the deformation was controled by the neck development in the plastic deformation zone.

Some researchers [40-42] recommended that the work needed to create a new fracture surface $\left(w_{e}\right)$ in DENT test can be expressed as the amount of the work for the plastic deformation prior to the necking inception and the work for the neck evolution and subsequent fracture. Accordingly, they formulated $w_{e}$ as:

$$
w_{e}=h \int_{0}^{\bar{\varepsilon}_{n}} \bar{\sigma} d \bar{\varepsilon}+\int_{\varepsilon_{n} h}^{\Delta F} \sigma\left(\Delta_{1}\right) d \Delta_{1}
$$

where $\bar{\sigma}$ and $\bar{\varepsilon}$ are the true stress and true strain in the fracture process region, respectively. The parameters $h$ and $\sigma$ are the height of the FPZ considered to be steady throughout the test and the engineering stress which is a function of the COD, respectively. The $\Delta_{1}$ and $\Delta_{\mathrm{F}}$ are the displacements during the necking process and the displacement at fracture, respectively.

The Eq. 4 shows two part that affect $w_{e}$, therefore the value for crack development can be separated into $w_{e, I}$ and $w_{e, I I}$ [40-43] which represent the parameter $w_{e}$ for the neck initiation in FPZ and neck growth in FPZ to the complete fracture, respectively. It can be formulated in Eq. 5 and 6 as follows:

$$
\begin{gathered}
w_{e, I}=h_{I} \int_{0}^{\bar{\varepsilon}_{n, \max }} \bar{\sigma} d \bar{\varepsilon} \\
w_{e, I I}=h_{I I} \int_{\varepsilon_{n, \max }}^{\bar{\varepsilon}_{f}} \bar{\sigma} d \bar{\varepsilon}
\end{gathered}
$$

where $\bar{\varepsilon}_{n \text {,max }}$ and $\bar{\varepsilon}_{f}$ are the greatest value corresponding to the true strain at the neck initiation and the equivalent true strain at the complete fracture, respectively. The Eq. 5 and Eq. 6 are applied with the consideration that the strain in FPZ is stable during initiation to neck growth [43].

Based on the EWF concept, the total energy needed in the neck initiation stages is the sum of work for initiating the neck through the whole ligament and the work for the neck growth in the $\ell_{i} / 2$ length from the initial ligament length. Therefore, the EWF can be written mathematically as:

$$
\begin{gathered}
W_{e, i}=2 t_{0}\left[\int_{0}^{\ell_{0} / 2} w_{e, 1} d \ell+\int_{0}^{\ell_{i} / 2} w_{e, 2} d \ell\right] \\
W_{e, p}=2 t_{0} \int_{\ell_{i} / 2}^{\ell_{0} / 2} w_{e, 2} d \ell
\end{gathered}
$$

The $w_{e}$ can be determined by dividing Eq. 7 and Eq. 8 by the ligament area $\left(\ell_{i .} t_{0}\right)$, so it can be expressed as: 


$$
\begin{gathered}
w_{e, i}=\left(1+\frac{1}{\eta}\right) w_{e, I}+w_{e, I I} \\
w_{e, p}=w_{e, I I}
\end{gathered}
$$

where $\eta=\ell_{p} / \ell_{0}$. The Eq. 9 and 10 indicate that $w_{e, i}$ is more than $w_{e, p}$ by the inclusion of $\left(1+\frac{1}{\eta}\right) w_{e, I}$ and the difference in height $\left(h_{1}\right.$ and $\left.h_{2}\right)$ has practically no effect.

At $\alpha$ shifting from $0^{\circ}$ to $22.5^{\circ}$, the $w_{e}$ decrease, which means that the work for the formation of new crack surfaces also decreases, the fracture energy is consumed for non-essential work $\left(\beta w_{p}\right)$, namely work in the plastic deformation zone. At an angle of fiber orientation above $22.5^{\circ}$, the decrease in $w_{e}$ turns out to be accompanied by a decrease in non-essential work $(\beta w p)$. The fracture toughness represented by $w_{e}$ and COD at the angle of fiber orientation shifted from $0^{\circ}$ was confirmed by the difference in $h_{I}$ and $h_{I I}$ values, which had no significant effect as shown in Eq. 9 and 10.

\subsection{Fracture surface morphology}

The SEM images showing the fracture surface morphology are shown in Fig 7. In the SF orientation of 0 or SF in the same direction as the loading direction (Fig. 7a), no matrix bonded in fiber interface, which was pulled out indicated poor interface bonding between fibers and matrix. The fractured surface clearly shows extensive matrix deformation. The presence of matrix crazings and ligaments indicates a ductile fracture occurred. These phenomena are also shown in composites with SF orientation of 22.5 . Also, the presence of agglomerating zeolites in Fig. $7 \mathrm{~b}$ shown in the yellow rectangle. This zeolite agglomeration supports brittle fracture behavior.

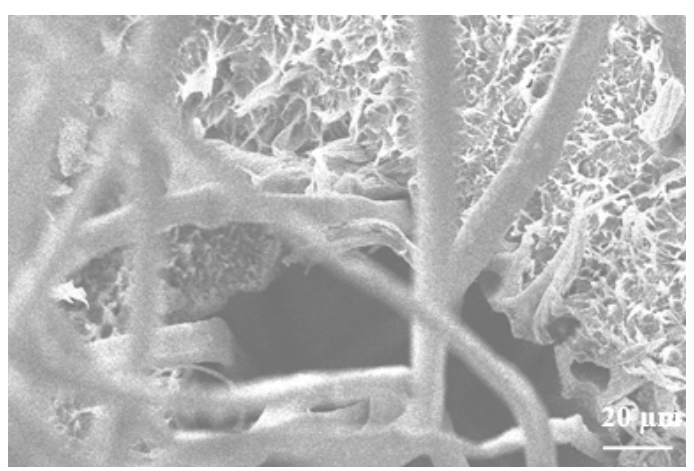

(a)

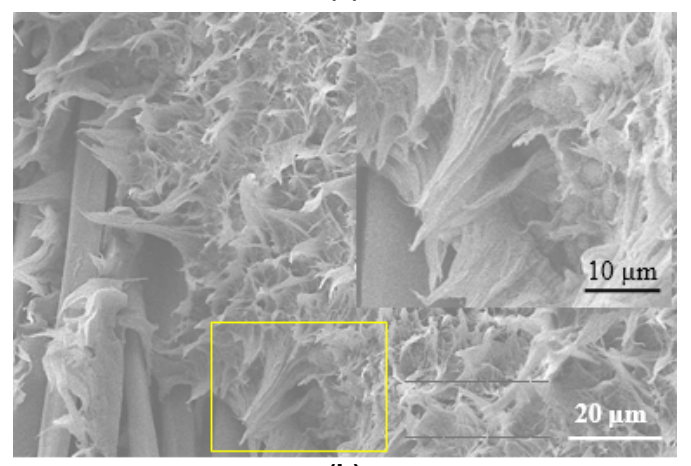

(b)

Figure 7. Fracture surface morphology for SF-Z/HDPE with SF orientation angle of (a) $0^{\circ}$, and (b) $22.5^{\circ}$. Insert image is the magnification of the image in a yellow rectangle

\section{CONCLUSION}

The mechanical properties of SF-reinforced Z/HDPE composites have been evaluated with different reinforcing fibre orientation. The fiber orientation angle determines the level of reinforcement of the material properties. The fracture energy is decreased by increasing deviation of the fibers orientation towards the load direction which indicates the fracture toughness of the composite decreases and brittle fracture occurs more easily. In addition, the COD which represents resistance to fracture initiation decreases by remembering the angle of orientation of the fiber. This phenomenon indicates that the deformation capacity in the outer plastic zone is decreasing by increasing the orientation of the fiber.

Future work is planned to investigate the influence of trimethyl methoxysilane to mechanical behavior of SF-Z/HDPE. In addition, a pressure annealing treatment is also planned to improve the crystallinity of the matrix to produce a composite with fit fiber orientation with a good bonding strength of the composite constituent elements.

\section{ACKNOWLEDGMENT}

The authors would like to thank the Directorate of Research and Community Service, Directorate General of Strengthening Research and Development, The Ministry of Research, Technology, and Higher Education of Indonesia for funding for this work.

\section{REFERENCES}

[1] Cordin, M., Bechtold, T., Pham, T.: Effect of fibre orientation on the mechanical properties of polypropylene-lyocell composites, Cellulose, Vol. 25, No. 12, pp. 7197-7210, 2018.

[2] Rajak, D.K., Pagar, D.D., Menezes, P.L., Linul, E.: Fiber-reinforced polymer composites: manufacturing, properties, and applications, Polymers, Vol. 11, No. 10, pp. 1667, 2019

[3] Sharma, B.N., Naragani, D., Nguyen, B.N., Tucker, C.L. and Sangid, M.D.: Uncertainty quantification of fiber orientation distribution measurements for long-fiber-reinforced thermoplastic composites, Journal of Composite Materials, Vol. 52, No. 13, $002199831773353,2017$.

[4] Meyer, J.J. and Adams, D.E.: Detecting changes in fiber orientation in a simulated chopped fiber plate using curvature mode shapes, Journal of Applied Mechanics, Vol. 85, No. 5, 051009, 2018.

[5] Raney, J.R., Compton, B.G., Mueller, J., Ober, T. J., Shea, K. and Lewis, J.A.: Rotational 3D printing of damage-tolerant composites with programmable mechanics, Proceedings of the National Academy of Sciences, Vol. 115, No. 6, pp. 1198-1203, 2018.

[6] Qu M., Nilsson, F. and Schubert, D.W.: Effect of filler orientation on the electrical conductivity of carbon fiber/PMMA composites, Fibers, Vol. 6, No. 1, pp. 3, 2018.

[7] Russell, T., Heller, B., Jack, D.A and Smith, D.E.: Prediction of the fiber orientation state and the 
resulting structural and thermal properties of fiber reinforced additive manufactured composites fabricated using the big area additive manufacturing process, Journal of Composites Science, Vol. 2, No. 2, pp. 26, 2018.

[8] Kim, J-W., Lee, D-G.: Study on the fiber orientation during compression molding of reinforced thermoplastic composites, International Journal of Precision Engineering and Manufacturing-Green Technology, Vol. 1, No. 4, pp. 335-339, 2014.

[9] Pienti, L., Sciti, D., Silvestroni, L. and Guicciardi S.: Effect of milling on the mechanical properties of chopped SiC fiber-reinforced $\mathrm{ZrB} 2$, Materials, Vol. 6, No. 5, pp. 1980-1993, 2013.

[10] Sambale, A.K., Schöneich, M. and Stommel, M.: Influence of the processing parameters on the fibermatrix-interphase in short glass fiber-reinforced thermoplastics, Polymers, Vol. 9, No. 6, pp. 1-23, 2017.

[11] Nakao, R., Inoya, H. and Hamada, H.: Mechanical properties of injection molded products fabricated by direct fiber feeding injection molding, Energy Procedia, Vol. 89, pp. 307-312, 2016

[12] Thilagavathi, G. and Viju, S.: 11 - Silk as a suture material, in A. Basu (Ed.): Advances in Silk Science and Technology, Woodhead Publishing, pp. 219232, 2015.

[13] Gil, E.S., Kluge, J.A., Rockwood, D.N., Rajkhowa, R., Wang, L., Wang, X. and Kaplan, D.L.: Mechanical improvements to reinforced porous silk scaffolds, J Biomed Mater Res A, Vol. 99, pp. 1628, 2011.

[14] Rockwood, D.N., Gil, E.S., Park, S.H., Kluge, J.A., Grayson, W., Bhumiratana, S., Rajkhowa, R., Wang, X., Kim, S.J., Vunjak-Novakovic, G. and Kaplan, D.L.: Ingrowth of human mesenchymal stem cells into porous silk particle reinforced silk composite scaffolds: An in vitro study, Acta Biomater, Vol. 7, pp. 144-51, 2011.

[15] Rajkhowa, R., Gil, E.S., Kluge, J., Numata, K., Wang, L., Wang, X. and Kaplan, D.L.: Reinforcing Silk Scaffolds With Silk Particles, Macromol Biosci, Vol. 10, No. 6, pp. 599-611, 2010.

[16] Mandal, B.B., Grinberg, A., Gil, E.S, Panilaitis, B. and Kaplana, D.L.: High-strength silk protein scaffolds for bone repair, Proc Natl Acad Sci U S A, Vol. 109, No. 20, pp. 7699-7704, 2012.

[17]Zhang, Y., Wu, C., Friis, T., Xiao, Y.: The osteogenic properties of $\mathrm{CaP} / \mathrm{silk}$ composite scaffolds, Biomaterials, Vol. 31, No. 10, pp. 2848 2856, 2010.

[18]Khan, Y., Yaszemski, M.J., Mikos, A.G. and Laurencin, C.T.: Tissue engineering of bone: material and matrix considerations, J Bone Joint Surg Am, Vol. 90, No. 1, pp. 36-42, 2008.

[19] Farokhi, M., Mottaghitalab, F., Samani, S., Shokrgozar, M.A., Kundu, S.C., Reis, R.L., Fatahi, Y. and Kaplan, D.L.: Silk fibroin/hydroxyapatite composites for bone tissue engineering, Biotechnology Advances, Vol. 36, No. 1, pp. 68-91, 2018.
[20]Pereira, R.F.P., Silva, M.M. and de Zea Bermudez, V.: Bombyx mori silk fibers: an outstanding family of materials, Macromol. Mater. Eng, Vol. 300, No. 12, pp. 1171-1198, 2015.

[21]Liu, J.B., Tang, Q., Lu, S., Zhang, C. and Li, M.Z.: Preparation and characterization of silk fibroin/ hydroxyapatite bilayer scaffolds, Advanced Materials Research, Vol. 415-417, pp. 1810-1815, 2011

[22] Tamjid, E., Bagheri, R., Vossoughi, M. and Simchi, A.: Effect of particle size on the in vitro bioactivity, hydrophilicity and mechanical properties of bioactive glass-reinforced polycaprolactone composites, Materials Science and Engineering C, Vol. 31, No. 7, pp.1526-1533, 2011

[23] Purnomo et al.: Zeolite-based biomaterials for biomedical application: A review, AIP Conference Proceedings, Vol., 1977, 030013, 2018.

[24] Ma, R. and Tang, T.: Current Strategies to Improve the Bioactivity of PEEK, Int J Mol Sci, Vo. 15, No. 4, pp. 5426-5445, 2014.

[25] Purnomo and Setyarini, P.H.: Atmospheric-pressure annealing effect on the impact fracture toughness of injection-molded zeolite-HDPE composite, International Review of Mechanical Engineering, Vol. 12, No. 6, pp. 556-562, 2018.

[26] Purnomo, Subri, M., Setyarini, P.: Fracture development and deformation behavior of zeolite-filled high density polyethylene annealed composites in the plane stress fracture, FME Transactions, Vol. 46, No. 2, pp. 165-170, 2018.

[27] Williams, J.G. and Rink, M.: The standardisation of the EWF test, Engineering Fracture Mechanics, Vol. 74, No. 7, pp. 1009-1017, 2007.

[28] Clutton, E.: Essential work of fracture, in: Moore, D.R., Pavan, A., Williams, J. (Ed): Fracture mechanics testing methods for polymers, adhesives and composites, Amsterdam: Elsevier, pp. 177-95, 2001.

[29] Clutton, E.: ESIS TC4 experience with the essential work of fracture method, in: Williams, J. G. and Pavan, A. (Ed): Fracture of polymers, composites and adhesives, Amsterdam: Elsevier, pp. 187-99, 2000.

[30] Martinez, A.B., Gamez-Perez, J., Sanchez-Soto, M., Velasco, J.I., Santana, O.O. and Maspoch, M.L.1.: The Essential Work of Fracture (EWF) method - analyzing the post-yielding fracture mechanics of polymers, Eng. Fail. Anal, Vol. 16, pp. 2604-2617, 2009.

[31] Kuno, T., Yamagishi, Y., Kawamura, T. and Nitta, K.: Deformation mechanism under essential work of fracture process in polycyclo-olefin materials, Express Polym Lett, Vol. 2, pp. 404-412, 2008.

[32]Rink, M., Andena, L., Marano, C.: The essential work of fracture in relation to J-integral, Engineering Fracture Mechanics, Vol. 127, pp. 46-55, 2014.

[33] Wang, J., Wang, G.Z., Xuan, F.Z. and Tu, S.T.: Derivation of constraint-dependent J-R curves based on modified T-stress parameter and GTN model for a low-alloy steel, International Journal of Fracture, Vol. 183, No. 2, pp. 155-168, 2013. 
[34] Grbović, A.M., Rašuo, B.P., Vidanović, N.D. and Perić, M.M.: Simulation of crack propagation in titanium mini dental implants (MDI), FME Transactions, Vol. 39, No. 4, pp. 165-170, 2011.

[35] Costa, F.R., Satapathy, B.K., Wagenknecht, U., Weidisch, R. and Heinrich, G.: Morphology and fracture behaviour of polyethylene $/ \mathrm{Mg}-\mathrm{Al}$ layered double hydroxide (LDH) nanocomposites, European Polymer Journal, Vol. 42, No. 9, pp. 2140-2152, 2006.

[36] Chen, Y.H., Mai, Y.W., Tong, P. and Zhang, L.C.: Numerical simulation of the essential work of fracture method, in: Williams, J.W. and Pavan, A. (Ed): Fracture of polymers, composites and adhesion, ESIS Publication, Amsterdam: Elsevier, pp. 175, 2000.

[37] Arkhireyeva, A., Hashemi, S., O`Brien, M.: Factors a ecting work of fracture of uPVC film, Journal of Materials Science, Vol. 34, pp. 5961-5974, 1999.

[38] Hashemi, S. and Williams, J.G.: Temperature dependence of essential and non-essential work of fracture parameters for polycarbonate film, Plastics Rubber and Composites, Vol. 29, No. 6, pp. 294302, 2000.

[39] Hashemi, S.: Work of fracture of high impact polystyrene (HIPS) film under plane stress conditions, Journal of Materials Science, Vol. 38, No. 14, pp. 3055-3062, 2003.

[40] Mai, Y-W., Cotterell, B., Horlyck, R. and Vigna, G.: The essential work of plane stress ductile fracture of linear polyethylenes, Polymer Engineering and Science, Vol. 27, No. 11, pp. 804809, 1987.

[41] Mai, Y-W.: On the plane-stress essential fracture work in plastic failure of ductile materials, International Journal of Mechanical Sciences, Vol. 35, No. 12, pp. 995-1005, 1993.

[42] Wu, J. and Mai, Y-W.: The essential fracture work concept for toughness measurement of ductile polymers, Polymer Engineering and Science, Vol. 36, No. 18, pp. 2275-2288, 1996.

[43] Kwon, H.J. and Jar, P.-Y. B.: Application of essential work of fracture concept to toughness characterization of high-density polyethylene, Polymer Engineering and Science, Vol. 47, No. 9, pp. 1327-1337, 2007.

\section{NOMENCLATURE}

$\alpha \quad$ Silk fibers orientation angle

$W_{f} \quad$ Total work of fracture

$W_{e} \quad$ Essential work of fracture

$W_{p} \quad$ Non-essential work of fracture

$t \quad$ Ligament thickness

$\ell \quad$ Ligament length

$w_{f} \quad$ Specific total work of fracture

$w_{e} \quad$ Specific essential work of fracture $\beta w_{p} \quad$ Specific non-essential work of fracture

$\beta \quad$ Shape factor of the plastic zone

$d J / d a$ The slope of the $J$ - $R$ curve in $J$-integral method

a Initial crack length

$C_{f} \quad$ The plastic constraint factor

$\sigma_{y} \quad$ The yield stress of material

COD Crack opening displacement

FPZ Fracture process zone

$\bar{\sigma} \quad$ True stress in the fracture process region

$\bar{\varepsilon} \quad$ True strain in the fracture process region

$h \quad$ Height of the FPZ

$\sigma \quad$ Engineering stress

$\Delta_{1} \quad$ Displacements during the necking process

$\Delta_{\mathrm{F}} \quad$ Displacements at fracture

$\bar{\varepsilon}_{n, \max }$ The greatest value corresponding to the true strain at the neck initiation.

$\bar{\varepsilon}_{f} \quad$ The equivalent true strain at the complete fracture

$\ell_{0} \quad$ Initial ligament lenth

$\ell_{i} \quad$ Ligament length in neck inception stage

$\ell_{p} \quad$ Ligament length in neck growth stage

$W_{e, I} \quad$ The work for initiate the neck through the whole ligament.

$W_{e, P} \quad$ The work for the neck growth in the $\ell_{i} / 2$ length from the initial ligament length.

$w_{e, I} \quad$ The specific work for initiate the neck through the whole ligament.

$w_{e, P} \quad$ The specific work for the neck growth in the $\ell_{i} / 2$ length from the initial ligament length

$\eta \quad \ell_{p} / \ell_{0}$

$h_{1} \quad$ Height of the FPZ in neck initiation stage

$h_{2} \quad$ Height of the FPZ in neck growth stage

\section{УТИЦАЈ ОРИЈЕНТАЦИЈЕ ВЛАКАНА НА ЖИЛАВОСТ ЛОМА КОД Z/НDРЕ КОМПОЗИТА ОЈАЧАНИХ СВИЛЕНИМ ВЛАКНИМА}

\section{Пурномо, П.Х. Сетиарини, А.Д. Ангоно}

Истражује се жилавост лома и деформација код композита од зеолита/полиетилена високе густине (Z/HDPE) ојачаних свиленим влакнима. Уситњена свилена влакна су распоређена у дебелом слоју на средини сувог праха мешавине од Z/HDPE припремљене у калупу. Композити су добијени обликовањем компресијом да би се постигло двоструко зарезано затезање. Карактеристике жилавости лома су одређене методом анализе лома. Реултати показују да је присуство свилених влакана повећало рад лома иако је основни рад лома код Z/HDPE био већи него код S-Z/HDPE. Развој зоне пластичног ширења лома подудара се са процесом стварања зоне пукотине чија висина није имала утицаја на потрошњу енергије. 